\title{
Marked radiographic response of a HER-2- overexpressing biliary cancer to trastuzumab
}

\author{
This article was published in the following Dove Press journal: \\ Cancer Management and Research \\ 10 December 2013 \\ Number of times this article has been viewed
}

\section{Steven Sorscher \\ Washington University School of Medicine, Department of Oncology, St Louis, MO, USA}

\begin{abstract}
Trastuzumab is a monoclonal antibody targeting HER-2. HER-2 overexpression has been described in gallbladder cancer and in cholangiocarcinoma. This report describes the first case of a patient with HER-2 overexpressing metastatic gallbladder adenocarcinoma and responding radiographically and biochemically to trastuzumab alone.
\end{abstract}

Keywords: metastatic gallbladder adenocarcinoma, HER-2 overexpression, trastuzumab

\section{Case report}

$\mathrm{AK}$ is a 61-year-old woman who developed right upper quadrant pain and underwent a laparoscopic cholecystectomy on January 22, 2013. Operative findings included a "porcelain" gallbladder, an apparent liver metastasis, and peritoneal metastases. The gallbladder was removed and one liver lesion was biopsied. Pathology confirmed a poorly differentiated gallbladder adenocarcinoma and metastatic liver disease. Immunohistochemical stains were strongly positive for CK7, polyclonal CEA, and nuclear CDX-2. Based on the histology and immunostaining, the pathologist wrote "these findings are consistent with a gallbladder origin".

On February 5, 2013, chemotherapy was initiated with cisplatinum $\left(25 \mathrm{mg} / \mathrm{m}^{2}\right.$, days 1 and 8$)$ and gemcitabine $\left(1,000 \mathrm{mg} / \mathrm{m}^{2}\right.$, days 1 and 8$)$ every 21 days. After two cycles, her CA19-9 had increased from $1,070 \mathrm{U} / \mathrm{mL}$ to $3,769 \mathrm{U} / \mathrm{mL}(0-35 \mathrm{U} / \mathrm{mL})$ and a computed tomography (CT) scan of her chest/abdomen/pelvis showed "interval progression" of her metastatic liver disease (largest liver lesion now $8 \times 5 \mathrm{~cm}$ ).

Immunohistochemical staining revealed "HER-2 immunostain is strongly positive in the majority of tumor cells". The pathologist wrote "The clinical significance of this finding in these tumors is unknown". The pathologist noted that the staining would be the equivalent of $3+$ by immunohistochemistry for HER-2 had this been a breast cancer specimen or a gastric cancer specimen.

Breast and gastric cancers are the only tumors where HER-2 3+ staining is currently defined. The definition of 3+ staining for breast cancer is "very strong, complete, circumferential, membrane staining in 10\%-30\% of the tumor cells", and in gastric cancer the definition of $3+$ staining is strong, complete, basal lateral, or lateral membranous reactivity that is seen in greater than $10 \%$ of tumor cells.

On April 9, 2013, therapy was started with weekly paclitaxel $\left(80 \mathrm{mg} / \mathrm{m}^{2}\right)$ and trastuzumab (4 mg/kg loading dose followed by $2 \mathrm{mg} / \mathrm{m}^{2}$ ). Her CA19-9 improved from 4,143 U/mL on April 9, 2013 to 1,370 U/mL on May 21, 2013. A CT scan on May 20, 2013 showed "interval decrease in the size of the liver metastases", with the 
largest lesion having decreased in size from $8.5 \times 5 \mathrm{~cm}$ to $5.4 \times 3.8 \mathrm{~cm}$ ". There were no new lesions seen. Paclitaxel therapy was discontinued and the patient has remained on single-agent trastuzumab weekly. By June 26, 2013, her CA19-9 had improved to $432 \mathrm{U} / \mathrm{mL}$ and a repeat CT on July 1, 2013 showed "interval decrease in the size of the liver metastases", with the largest lesion having decreased in size from $5.4 \times 3.8 \mathrm{~cm}$ to $2.8 \times 2.1 \mathrm{~cm}$. She continued to receive trastuzumab alone, and a repeat CT scan on September 18, 2013 showed a further response of her metastatic disease to trastuzumab alone, with the largest liver lesion having decreased in size from $2.8 \times 2.1 \mathrm{~cm}$ to $1.3 \times 0.8 \mathrm{~cm}$. Again, there were no enlarging or new lesions.

\section{Discussion}

HER-2 is an ErbB tyrosine kinase family receptor. ${ }^{1,2}$ In breast cancer, trastuzumab is approved by the US Food and Drug Administration for use as part of adjuvant and metastatic disease therapy in patients with tumors that overexpress HER-2 as measured by immunohistochemistry (ie, 3+) or show HER-2 gene amplification by fluorescence in situ hybridization., ${ }^{3,4}$ Trastuzumab is also approved for use in combination with chemotherapy for patients with HER2-overexpressing metastatic gastric or gastroesophageal cancers. ${ }^{5}$

Biliary cancers are relatively rare cancers and include adenocarcinomas originating in the gallbladder or bile ducts. Once metastatic, these malignancies are considered incurable. Patients randomized to receive gemcitabine and cisplatinum showed a small overall survival benefit of 11.7 months compared with 8.1 months for those receiving gemcitabine alone. ${ }^{6}$ This combination has consequently become a standard first-line therapy for patients with metastatic biliary cancer. The cancer in our patient progressed while she received that combination, and there is no proven efficacy of second-line therapy for metastatic biliary cancer.

Only about $5 \%$ of biliary cancers overexpress HER-2..$^{7-10}$ AK's gallbladder adenocarcinoma did overexpress HER-2. While there is no formal definition of HER-2 $3+$ in biliary cancers, had her tumor been a breast or gastric cancer, it clearly would have met the criteria for HER-2 3+ overexpression, as described above. Over the time she received trastuzumab alone, her tumor responded both radiographically and biochemically to trastuzumab alone, with her CA19-9 improving from $1,370 \mathrm{U} / \mathrm{mL}$ to $432 \mathrm{U} / \mathrm{mL}$ and her largest liver lesion decreasing in size from $5.5 \times 3.8 \mathrm{~cm}$ to $1.3 \times 0.8 \mathrm{~cm}$, as noted in the radiology CT reports.
A review of the literature identified a single case report of a patient with biliary cancer responding to paclitaxel in combination with trastuzumab, ${ }^{11}$ but no previous report could be found of a patient responding to trastuzumab as a single agent. In this case, HER-2 overexpression was an actionable abnormality.

In summary, this metastatic gallbladder cancer was continuing to respond biochemically (ie, decreasing CA19-9) and radiographically to trastuzumab alone during the interval between May 20, 2013 and September 16, 2013. The durability of this response remains to be seen. Ideally, a study of patients with HER-2-overexpressing biliary cancer might confirm the benefit of using trastuzumab in patients with HER-2-overexpressing biliary cancer.

\section{Disclosure}

The author is on the Genentech speakers bureau for products other than trastuzumab. Otherwise, the author declares no relevant conflicts of interest in this work.

\section{References}

1. Olayioye MA, Neve RM, Lane HA, Hynes NE. The ErbB signaling network: receptor heterodimerization in development and cancer. EMBO J. 2000;19(13):3159-3167.

2. Yarden Y, Sliwkowski MX. Untangling the ErbB signalling network. Nat Rev Mol Cell Biol. 2001;2(2):127-137.

3. Vogel CL, Cobleigh MA, Tripathy D, et al. First-line Herceptin monotherapy in metastatic breast cancer. Oncology. 2001;61 Suppl 2: $37-42$.

4. Slamon D, Eiermann W, Robert N, et al. Adjuvant trastuzumab in HER2positive breast cancer. $N$ Engl J Med. 2011;365(14):1273-1283.

5. Bang YJ, Van Cutsem E, Feyereislova A, et al. Trastuzumab in combination with chemotherapy versus chemotherapy alone for treatment of HER2-positive advanced gastric or gastro-oesophageal junction cancer (ToGA): a phase 3, open-label, randomised controlled trial. Lancet. 2010;376(8742):687-697.

6. Valle J, Wasan H, Palmer DH, et al. Cisplatinum plus gemcitabine versus gemcitabine for biliary tract cancer. $N$ Engl J Med. 2010; 362(14):1273-1281.

7. Aishima SI, Tagucki KI, Sugimachi K, Shimada M, Sugimachi K, Tsuneyoshi M. c-erbB-2 and c-Met expression relates to cholangiocarcinogenesis and progression of intrahepatic cholangiocarcinoma. Histopathology. 2002;40(3):269-278.

8. Ito Y, Takeda T, Sasaki Y, et al. Expression and clinical significance of the erbB family in intrahepatic cholangiocellular carcinoma. Pathol Res Pract. 2001;197(2):95-100.

9. Ukita Y, Kato M, Tereda T. Gene amplification and mRNA and protein overexpression of c-erbB-2 (Her-2/neu) in human intrahepatic cholangiocarcinoma as detected by fluorescence in situ hybridization, in situ hybridization, and immunohistochemistry. $J$ Hepatol. 2002;36(6):780-785.

10. Yoshikawa D, Ojima H, Iwasaki M, et al. Clinical pathologic and prognostic significance of EGFR, VEGF and HER2 expression in cholangiocarcinoma. Br J Cancer. 2008;98(2):418-425.

11. Law LY. Dramatic response to trastuzumab and paclitaxel in a patient with human epidermal growth factor receptor 2-positive metastatic cholangiocarcinoma. J Clin Oncol. 2012;30(27):3271-3273. 


\section{Publish your work in this journal}

Cancer Management and Research is an international, peer-reviewed open access journal focusing on cancer research and the optimal use of preventative and integrated treatment interventions to achieve improved outcomes, enhanced survival and quality of life for the cancer patient The journal welcomes original research, clinical \& epidemiological studies, reviews \& evaluations, guidelines, expert opinion \& commentary, case reports \& extended reports. The manuscript management system is completely online and includes a very quick and fair peerreview system, which is all easy to use. Visit http://www.dovepress.com/ testimonials.php to read real quotes from published authors.

Submit your manuscript here: http://www.dovepress.com/cancer-management-and-research-journal 